Ann. Abeille, I965, 8 (4), 299-307.

\title{
COMPOSITION ET PROPRIÉTÉS DU POLLEN : REVUE DES TRAVAUX RECENTS
}

\author{
Marie-France IÜ̈GEL \\ Institut de Chimie des Substances naturelles, Gif-sur-Yvette (Seine-et-Oise)
}

SOMMAIRE

L'auteur analyse les différents articles et revues parus depuis Ig6o concernant le pollen : analyse chimique, étude des fractions allergisantes et facteurs conditionnant une bonne germination.

Dans ce bref aperçu, nous ne parlerons pas des travaux effectués avant I960; des revues plus anciennes et très complètes (LUNDEN, I956; JOHRI, I96I ; HÜGEL, I962) constituent de bons points de départ dans l'étude de la chimie et de la physiologie du pollen.

Il est intéressant de constater que 1'orientation générale des recherches dans le domaine du pollen a totalement changé au cours de ces dernières années. Les premiers travaux, publiés il y a déjà fort longtemps, concernaient surtout la constitution du grain. Les travaux d'analyse étant assez avancés, il semble qu'aujourd'hui le point de vue du physiologiste ait remplacé celui du chimiste.

Une première série d'articles concerne l'étude des phénomènes accompagnant la germination, et en particulier, les besoins nutritifs du tube pollinique. Une autre série se rapporte aux allergènes, à leur composition et à leur action physio-pathologique. On note encore quelques résultats d'analyses chimiques, mais l'essentiel des recherches porte actuellement, soit sur la nutrition, soit sur les propriétés alletgisantes.

Nous tenterons d'analyser successivement ces trois points de vue :

$I^{0}$ Nutrition, germination.

$2^{\circ}$ Allergie.

$3^{\circ}$ Composition chimique du pollen. 


\section{Nutrition, germination}

Le milieu le plus efficace pour une bonne germination est un milieu à base de saccharose (I5 à 20 p. TOO) (LABOUREUR, I960; FAEHNRICH, I964; VASIL, I964; DEAN, I964; StANley, I964; LAyNe, I964). On peut, d'après VASIL (I964), remplacer celui-ci par d'autres sucres tels que le glucose, le galactose, etc., mais le mannose ou le mannitol, par contre, diminuent le pourcentage de germination et empêchent le développement du tube (STANLEY, I964).

Le bore est un facteur indispensable à une bonne germination ; à la concentration de I $_{5}$ à 20 p.p.m., on obtient les meilleurs résultats. L'association bore-saccharose est indispensable à la germination (MUENZER, I962 ; LAYNE, I964 ; STANLEY, I964 ; DEAN, I964). Ajoutons que le bore ne peut être remplacé par aucun autre élément et que l'aluminium peut empêcher la croissance (FAEHNRICH et ULL,RICH, Ig64).

Le rôle des substances de croissance a été assez bien étudié ; l'acide giberellique peut induire le développement, mais ne peut remplacer le bore ; 1'acide indol-acétique n'a aucune action (FAEHNRICH et ULLRICH, I964); l'acide gibérellique peut également lever une inhibition provoquée, ceci à la dose de 100 à $500 \mathrm{\gamma} / \mathrm{cm}^{3}$ de milieu, ce que ne peut absolument pas faire l'acide indol-acétique (LABOUREUR, I960).

Une grande variété de produits a été essayée, soit pour augmenter le pourcentage de la germination, soit pour en augmenter la vitesse : la kinétine augmente la vitesse, mais non pas la quantité (GorkA-BRYLASS, I96I) ; les antibiotiques semblent n'avoir aucune action (SEN, I96I) ; les vitamines (riboflavine) augmentent le rendement jusqu'à une concentration de $200 \gamma$ pour $100 \mathrm{~cm}^{3}$ de milieu et ensuite joutent le rôle d'inhibiteurs (HoT's et al., I963) ; les acides dicarboxyliques (acide fumarique, succinique et adipique) semblent augmenter la vitesse de germination s'ils sont ajoutés au milieu à une concentration inférieure à o,o0I M (Pérrochenko, I964). Si l'on apporte au milieu certains sels comme ceux de calcium (300 à 500 p.p.m.) (BREWBAKER, I963), de manganèse (6 à 600 p.p.m.) (ZIELINSKI-OLEZ, I963) et de cuivre (35 p.p.m.) (HOEFFNER et al., I96r), on peut stimuler le développement.

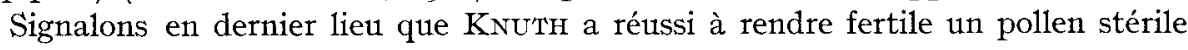
en ajoutant de la colchicine au milieu (I963).

On rencontre dans la littérature de nombreuses études cytologiques et physiologiques faites sur le pollen en voie de croissance :

- recherches sur l'utilisation des sucres (saccharose en particulier); ceux-ci tendent à se transformer en callose (KESsLER, I960 ; IwANAMr, I964). Le callose se trouve en grande quantité dans les plantes stériles; cette transformation, d'après les auteurs, doit toucher la chimie du phosphore, car dans ce cas on trouve une quantité plus importante de cytochrome-oxydase que de phosphatases (SCHLOESSER, I962) ; le saccharose est mobilisé plus rapidement que les autres sucres (TuPY, I962);

- la quantité d'azote reste constante, seule sa forme diffère : il y a protéolyse, puis resynthèse au moment de la croissance du tube (PozSA, I96I);

- le soufre se trouve sous forme de groupement sulfhydrile. Sa forme de transport est le glutathion (LINSKENS, I964; OREL, I964);

- on trouve aussi des recherches partielles effectuées sur l'action des acides ribonucléiques sur la germination (ALIMOVA, I962); 
- ont été étudiés aussi les effets dus à la conservation (SiNGH et al., r96I), ceux dus aux variations du $\mathrm{pH}$ du milieu de germination (TANAKA, I960), ceux qui résultent de variations de concentration des éléments constitutifs du milieu (BREWBAKER, I96I) ; mais il semble qu'il n'y ait aucune réponse satisfaisante à ces questions.

\section{Allergie}

Nous nous intéresserons tout d'abord aux moyens d'extraction, de localisation et d'identification des allergènes, ensuite aux études physiologiques faites avec les substances isolées.

\section{a) Isolement, identification.}

Les allergènes sont des protéines, de masse moléculaire plus ou moins élevée, liées à d'autres substances (RICHTER, I960 ; MALI EY, I962 ; RoBbINs, I963 ; KING, I964). On les isole, soit de fractions dialysables liées à des pigments et des sucres (RICHTER, I96I), soit des fractions non dialysables et, c'est le cas le plus fréquent, liées à des polysaccharides (xylose-acide glucoronique, arabinose-galactose, etc.) (LEA, I962). Les protéines isolées par LiNSKENS (I96I) forment deux complexes et libèrent après hydrolyse I7 acides aminés dont la méthionine.

\section{TABLEAU I}

\begin{tabular}{|c|c|c|}
\hline \multirow[t]{2}{*}{ Liste des acides aminés } & is par cert & eurs \\
\hline & $\begin{array}{l}\text { RICITTER } \\
(1961)\end{array}$ & $\begin{array}{c}\text { I.NSKEKS } \\
(1961)\end{array}$ \\
\hline Acide aspartique. & + & + \\
\hline Acide glutamique & + & + \\
\hline Acide cistéique $\ldots \ldots \ldots \ldots \ldots \ldots$ ! & + & + (Cystine) \\
\hline Glycine ......... & + & \\
\hline Hydroxyproline . . . . . . . . . & + & \\
\hline Alanine $\ldots \ldots \ldots \ldots \ldots \ldots$ & + & $\div$ \\
\hline Proline $\ldots \ldots \ldots \ldots \ldots \ldots \ldots \ldots$ & + & + \\
\hline Valine $, \ldots, \ldots, \ldots, \ldots, \ldots, \ldots$ & + & + \\
\hline Phénylanaline $\ldots \ldots \ldots \ldots \ldots \ldots \ldots$ & + & + \\
\hline Lysine $\ldots \ldots \ldots \ldots \ldots \ldots \ldots \ldots$ & + & + \\
\hline Arginine $\ldots \ldots \ldots \ldots \ldots \ldots \ldots$ & + & + \\
\hline Thréonine $\ldots \ldots \ldots \ldots \ldots \ldots \ldots$ & & + \\
\hline Méthionine $\ldots \ldots \ldots \ldots \ldots \ldots$. & & + \\
\hline Isoleucine $\ldots \ldots \ldots \ldots \ldots \ldots \ldots$ & & + \\
\hline Leucine ..................... & & + \\
\hline Tyrosine $\ldots \ldots \ldots \ldots \ldots \ldots \ldots$ & & + \\
\hline Histidine $\ldots \ldots \ldots \ldots \ldots \ldots \ldots \ldots$ & & + \\
\hline Tryptophane $\ldots \ldots \ldots \ldots \ldots \ldots \ldots$ & & + \\
\hline
\end{tabular}

Dans le tableau I, nous dressons la liste des acides aminés isolés par certains auteurs.

Le schéma d'isolement de ces protéines est le suivant : après extraction ( $\mathrm{pH}$ entre 3 et Io), on les précipite avec le sulfate d'ammonium (MAI,LEY et al., Ig6o ; 
LIDD, I962 et I963) puis on les dialyse : la fraction non dialysable est la plus active (Palmaskierna, ig60; PereimutTter, ig62 ; Caliaghan, ig62) ; cette fraction est ensuite, soit chromatographiée (PAlmaskierna, I960; PerflmutTer, I962), soit diazotée, soit complexée par des réactifs aussi variés que la $p$-amino-benzyl-cellulose, l'aminostyrène, la ninhydrine (Malley, ig63; Augustus, I96o ; Brennan, I96I ; Richter et al., ig62; BERnton et al., Ig62; BOOKMAN, I962).

b) Tests physiologiques.

La valeur antigénique des fractions allergisantes est suivie par:

- hémaglutination : les $\gamma$-globulines seules sont précipitées par les allergènes; (Augustus, I960; Augustus et Hayward, I960; Bernton, I962 ; Gyenes, ig62) ;

- formation de granulomes: L,INDNER et al. (I962) et MEI,ON (Ig62) ont observé une prolifération abondante au niveau des injections;

- des tests de sensibilité de la peau : ce sont les plus faciles et les plus sensibles, ils sont employés comme moyen de contrôle (MALLEY et al., ig6o; BoOKMan, I962; Perelmutter et al., I962; LEA, I962).

Les allergènes sont très spécifiques, leur composition varie dans une même espèce en fonction des races ou des variétés (FEINBERG, I960).

\section{a) Acides aminés.}

\section{Constituants du grain de pollen}

Ce sont eux qui intéressent le plus vivement les chercheurs ; ce regain d'intérêt provient vraisemblablement du fait qu'ils entrent dans la composition des allergènes et sont importants pour la nutrition au moment de la germination;

- le pourcentage d'azote total est d'environ 3 p. IOo (NAvARA, I96r), celui des acides aminés ou des protéines est variable : I4 à 27 p. IOO (BIEBERDORF, Ig6I ; PERLsON, I963);

- les acides aminés isolés sont les acides aminés essentiels (PETrRovsKaya, ig62 ; TuPy, I963; Navara, I963). Des études comparatives ont été faites entre les pourcentages d'acides aminés trouvés dans le pollen et ceux trouvés dans d'autres tissus (TUlEcke et al., I963). Britikov (Ig64) s'est attaché à suivre les transformations de la proline au cours du temps, elle s'accumule après la méiose et elle est répartie uniformément sur les protoplastes.

b) Acides nucléiques.

En ce qui concerne les acides ribonucléiques et désoxyribonucléiques, peu de travaux sont à signaler. RoDkIEWICZ (I96I) s'intéresse aux variations de la teneur au cours de la germination. STANLEY (I962) étudie l'incorporation de la thyamine marquée dans le noyau reproducteur ; une équipe russe (VANYNskI et FAs, I96I) a essayé de calculer les concentrations en acides nucléiques dans un certain nombre de pollens $(0,6$ à I2 p. IOO).

c) Sucres.

Très peu de travaux là aussi ; ils traitent en général de la composition; les sucres les plus fréquemment rencontrés sont le fructose, le glucose et le saccharose (STANLEY, Ig62; Motomura et al., I962; Schanderl, I963). 
BOVENG (I963) a isolé dans certains pollens des polysaccharides, xylogalactutonane, arabinogalactane, etc.

Escrvich (I963) a mis au point les méthodes de dosage du callose.

TABLEAU 2

\begin{tabular}{|c|c|c|c|c|c|c|}
\hline \multicolumn{7}{|c|}{$\begin{array}{l}\text { Pourcentages des sucres } \\
\text { (Motomura et al., 1962) }\end{array}$} \\
\hline & $\begin{array}{l}\text { Typha } \\
\text { latifolia }\end{array}$ & $\begin{array}{c}\text { Pinus } \\
\text { thunbergii }\end{array}$ & $\begin{array}{c}\text { Lilium } \\
\text { auratum }\end{array}$ & $\begin{array}{c}\text { Lilium } \\
\text { lancifolium }\end{array}$ & $\begin{array}{l}\text { Cucurbita } \\
\text { moschata }\end{array}$ & $\begin{array}{c}\text { Oenothera } \\
\text { lamarckiana }\end{array}$ \\
\hline Fructose ... & ${ }_{1}^{\prime}+3, X^{\prime}$ & 3,19 & 25,96 & 21,52 & 12,21 & 27,14 \\
\hline Glucose ..... & 34,62 & 3,27 & $23,8^{\prime} \mathbf{t}$ & $2 / 4,81$ & 21,11 & 20,29 \\
\hline Saccharose.. & 21,54 & $93,5^{\prime} \mathbf{k}$ & 50,21 & 53,68 & 54,04 & 54,04 \\
\hline
\end{tabular}

Gladyshev (Ig62) a trouvé dans le pollen de blé deux hexosamines qu'il n'a pas identifiées.

Solovich et al. (I964) ont étudié les transformations enzymatiques que subissent les sucres dans le pollen de rose.

d) Pigments.

Mentionnons pour mémoire les travaux de Hisamichi (I96I) et de SAmorodovaBIAKI (Ig62) sur les caroténoïdes et ceux de TAKIGUChI (I964) sur la diminution de la flavine mononucléotide au moment de la germination.

e) Acides gras.

La teneur en acides gras est très variable : 8 p. Ioo selon Scotr (I962), I p. Ioo selon Ching (rg62); ces deux auteurs ont isolé les acides palmitique, oléique, linoléique, linolénique et stéarique, sous forme de triglycérides.

f) Stéroides.

Nous pouvons mentionner l'œstrone isolée du pollen de palmier dattier par RIDI (Ig60), le méthylène-24-cholestérol (BARBIER et HÜGEI, I960), une série bio-

TABLEAU 3

Pourcentage du poids sec

\begin{tabular}{|c|c|c|c|c|}
\hline & $\begin{array}{l}\text { Typha } \\
\text { latifolia }\end{array}$ & $\begin{array}{c}\text { Pinus } \\
\text { thunbergii }\end{array}$ & $\begin{array}{l}\text { Lilium } \\
\text { auratum }\end{array}$ & $\begin{array}{c}\text { Lilium } \\
\text { lancifolinm }\end{array}$ \\
\hline Eau .... & 16 & 9,12 & 4,20 & 2,68 \\
\hline Protéines & 20,7 & 17,87 & 25,93 & 23,29 \\
\hline Cendres... & 4,05 & 4,69 & 4,00 & 4,17 \\
\hline Amidon $\ldots \ldots \ldots \ldots \ldots$ & 12,39 & 2,59 & 1,41 & 3,61 \\
\hline Sucres réducteurs ........ & 6,15 & 2,01 & 10,43 & 11,47 \\
\hline Sucre inverti $\ldots \ldots \ldots \ldots$ & 6,57 & 4,96 & 10,81 & 11,62 \\
\hline
\end{tabular}


synthétique de stérols isolée de différents pollens (HÜGEL, I964) et un nouveau stérol s'apparentant aux triterpènes: le pollinastanol isolé d'un pollen mixte (HÜGEI, I964).

Pour terminer cette revue, nous signalerons des articles d'intérêt général, ceux de Shpakova (I960 et I962) et celui de Motomura et al. (I962) déjà mentionnés et d'où nous tirons le tableau général $n^{0} 3$.

\section{CONCL,USION}

Ce rapide survol de la littérature concernant le pollen n'a eu pour but que de préciser la direction des recherches actuelles. Il est intéressant de noter que certains domaines sont exploités systématiquement (allergie, germination) tandis que d'autres restent encore à explorer (bio-synthèse des stérols, des sucres, etc.) et d'autres ne sont mêmes pas effleurés (attractivité des pollens vis-à-vis des abeilles).

Recu pour publication en sepiembre 1965.

\section{SUMMARY}

THE COMPOSITION AND CHARACTERISTICS OF POLLEN :

A REVIEW OF RECENT WORK

Various articles and reviews on pollen which have appeared since 1960 are discussed. The headings include chemical analysis, the study of allergising fractions, and factors conditioning satisfactory germination.

\section{RÉFÉRENCES BIBLIOGRAPHIQUES}

Alinovi G. K., rg62. Cytochemical studies of the development of pollen grains in corn plants. Bot. $Z ., 47,15^{22-1} 5^{27}$.

Augustus R., IIAYward B. J., Iongbotton J. L., Ig6o. Isolation and characterisation of reagins blocking antibodies and precipitation to grass pollens. Acta allergol., $7,3^{1-37}$.

Augustus R., HaYwari B. J., r960. Human reagins to grass pollen and modd. /. Immunol., 3, 45-73.

Augustus R., ITaywari I3. J., ig60. Grass pollen and modd antigens and their antibodies including reagins. Chem. Abs., 54, I $76+\mathrm{r} d$.

Barbier M., HëGei M. F., LeDerer E., Ig6o. Isolement du 24-méthyléne cholestérol à partir du pollen de différentes plantes. Bull. Soc. Chim. Biol., 42, 9i-97.

Bernton H. S., Chambers D. C., Querry B. V., ig62. Comparaison of results of various tests for blocking antibodies. Ann. Allergy, 20, $511-516$.

Bieberdorf F. W., Gross A. L., Weichleis R., t961. Free amino acids content in pollen. Ann. Allergy, 19, $867-876$.

BoOkma N. R., SAEN J., 1962. Standardisation of some characteristics of ragweed pollen antigens by paper electrophoresis. J. Lab. Clin. Med., 59, 293-301.

Boveng II. O., 1963. Polysaccharids in pollen. Phytochemistry', 2, 341-352.

BrenNax li. C., Ig61. A spectrophotometric procedure for determining total allerginic protein in allerginic extracts. Chem. Abs., 55, $13766 \mathbf{e}$.

BREWBAKER J. I.,' 1963 . Fssential role of $\mathrm{Ca}$ ion in pollen germination and pollen tube growth. Amer. J. Bot., 50, $859-805$. 
Brewbaker J. I., Mascumber S. K., r96r. Cultural studies of the pollen population effect and selt incompatibility inhibition. Amer. J. Bol., 48, 457-464.

Britikov E. A., Musatova N. A., 1964. Accumulation of free proline in the pollen. Chem. Abs., 61, $735^{8} h$.

Callaghan O. H., Goldfarb A. R., ig62. Isolation and properties of an allergen from dwarf ragweed pollen. J. Immunol., 89, 61 2-622.

Ching T. M., Ching K. K., ig63. Fatty acids of same coniferous species. Science, 138, $890-891$.

Dean C. F., I964. Sucrose and boron in artificial media for baccopollen germination and tube growth. Tobacco Sci., 8, 6o-64.

Eschvich N., 1963. Cytoplasmic connections between the pollen mother cells of $C$. ficilolia under the electron microscope. Protoplasma, 56, 718-722.

FaElinkich P., I964. The germination of pollen and growth of pollen tube. Plan!a, 61, I87-195.

FAEHnRicit P., Ulirtch H., I964. Germination of pollen and growth of pollen tube. Planta, 62, 39-50.

FEInberg J. G., I960. Immunological inadequacy randomly selected grass pollen extracts in specific hay-fever therapy. Internation. Arch. Allergy appl. Immunol., 16, 1-i 6.

Gladyshev B. N., 1962. Hexosamin containing compounds of mucoprotein type in corn pollen. Biokhimya, 27, 240-245.

Gyenes I., SEHON A. J., 1962. Mechanism of hemaglutination reaction. J. Immunol., 89, 483-480.

Gorska-Brylass A., Ig6r. The effect of kinetin on pollen germination and pollen tube growth. Chem. Abs., 55, $1808 \mathrm{i}$.

Hüger. M.-F., I 962 . Étude de quelques constituants du pollen. Ann. Abeille, 5, 97-133.

Hügel M.-F., Barbier M., Lederer E., I954. Sur le pollinastanol, nouveau stérol du pollen. Bull. Soc. Chim. France, 2012-2013.

Hügel M.-F., Vetter W., Autier H., Barbier M., Lederer E., ig64. Analyse des stérols du pollen par spectrométrie de masse. Phytochemistry, 3, 7-I6.

IIofffier W., Schamulveffel E., Voelkeri. I., i961. Micrometric content of flowers and portions of seeds of some graminae. Planta, 5\%, 608-612.

Hotтa K., TAkigucii K., Otsuki K., ro53. Effect of riboflavin and other factors on the rermination of pollen and on the pollen tube. Chem. Abs., 59, i $587 \mathrm{~d}$.

IIsAmich S., I96r. Microchemical investigations of the distribution of pollen flavonoid components. Chem. Abs., 55, I $66066 \mathrm{~h}$.

Iwanami Y., 1964. Physiologrical studies on pollen. Chem. Abs., 61, I $5022 b$.

Joiri B. M., Vasiur K., 196r. Physiology of pollen. Bot. Rev., 27, 326-381.

Kessler G., Feingoin D. S., Hassid W. Z., ig60. Utilisation of exogenous sugars for biosynthesis of carbohydrates in germinating pollen. Plant Physiol., 35, 505-509.

King T. P., Norman P. S., Convell J. T., I964. Isolation and characterisation of allergens from ragweed pollen. J. Immunol, 87, 439-446.

KNutil M., I963. Colchicine treatment of the begonia Gloire de Lorraine variety. Chem. Abs., 59. $7866 n$.

I.ABolireur P., ig6o. Interaction de l'acide gibérellique sur la germination du pollen de tulipe. C. $R$. Acad. Sci, 250, I 7 I 5-I 7 I 7 .

IAYNE R. E. C., IIAGEDOR N. D. J., ig64. Fiffect of boron and agar on germination of pea pollen in sucrose media. Chem. Abs., 60, I3828g.

J.EA D. J., SEIION A. H., ig62. Chemical characterization of non dialysable constituents of ragweed pollen. Internation. Arch. Allergy Appl. Inmunol, 20, 203-209.

LEA D. J., SEHoN A. H., I 962 . The skin activity of non dialysable constituents of ragiveed pollen. Inlernation. Arch. Allergy Appl. Immunol, 20, 220-227.

LIJD D., FARR R. S., 1962. Primary interreactions between I ${ }^{131}$ labeled ragweed pollen and antibodies in the serum of humans and rabbits. J. Allergy, 33, 45-58.

LIDD D., FARR R. S., ig63. Similities between antigens derived from ragweed pollen and from other botanical sources. f. Allergy, 34, 48-62.

Linuner A., Turam-Kutam A., Sokatcil J. R., Hammarsteix J. F., 1962 . Experimental granuloma formation with pine pollen. Exper. Mol. Pathol., 1, 470-480.

I.inskens II. F., Seprauwen J. A. M., 1964. Changes in the content of SH group during miosis and development. Chem. Abs., 60, 7148d.

Inskexs H. F., 196r. The question of the origin of the antibodies in the incompatibility reaction of petunia. Chem. Abs., 55, 16700 $e$.

LUNDEN R., I956. Literature on pollen chemistry. Grana palynol., 1-2, 3-2 I.

MALley A., ReEd L. E., Lietze A., 1962. Isolation of allergens from timothy pollen. J. Allergy, 33, 84-94.

Mailey A., Lietze A., Reed C. F., i96o. Separation of substances in timothy pollen extract producing allergic skin reaction from those producing hemaglutination reactions. J. Allergy, 31, 413-420. 
Malley A., Campbell D. H., I963. Isolation of antibody by moans of an immunologic adsorbent. $J$. amer. Chem. Soc., 85, 487-488.

Melon J., Lecomte J., 1962. Etude comparative des effets de la bradykine et des réactions anaphylactiques locales chez l'homme. Internation. Arch. Allergy Appl. Inmmunol., 21, 89-98.

Motomura Y., Watanabe T., Aso K., ig62. Honey and pollen. Tohoku J. Agric. Rev., 13, $237^{-244 .}$

Muenzer R., 1962. The physiology of pollen germination and pollen tube development with special reference to the effect of $\mathrm{H}_{3} \mathrm{BO}_{3}$. Chem. Abs., 56, 9r43e.

Navara A., Uhliar J., rg6r. Nitrogen content and levels of amino acids in the pollen of corn. Biologica (Bratislava), 16, 688-693.

Navara A., POspisilova D., I963. The content of sugars and amino acids in the pollen of $V$. vinifera. Chem. Abs., 59, 5497 g.

ORELL L. I., I 964 . Histochenical study of formation of gynecium and pollen in tomato plants. Chem Abs., 61, $9777 \%$.

Palmstiekna H., 1960. The purification of allergens. Sc. Tools, 7, 29-33.

Perlmutter L., Lea D. J., Freedman S. O., Sehon A. H., I962. Demonstration of precipiting antibodies in serums of ragweed allergic individuals by the agar technique. Internation. Arch. Allergy Appl. Immunol., 20, 355-367.

Perelmutter L., Freedman S. O., Sehon A. H., 1962. Demonstration of multiple hemaglutinating factors in serums of ragweed allergic individuals with the help of immunosorbent. $/$. Immunol., 89, 623-63I.

Perelson I. E., rg63. Amino acids composition of pollen of several honey carriers and pollen carriers. Chem. Abs., 59, 5492 e.

Petrochenko U. A., 1964. Effect of dicarboxylic acids on pollen grermination and growth of pollen tube. Chem. Abs., 61, 4720h.

Petrovskaya T. P., Tsinger N. V., ig62. Free amino acids and sugars in pollen and anthers of wheatwheat grass first generation hybrides and its parental plants. Chem. Abs., 56, I4647 a.

Pisani S., Gatto E., Sanchez de la VEGA, ig6o. Chromatographic separation of pollen antigens. Rev. Arg. Allergica, 7, 1-8.

Pozsa B. I., I96r. The nitrogen metabolism of the pollen and its function in fertilisation. Chem. Abs.? 55, $12558 i$.

Richter M., Griffith $\quad$ B. W., Rose B., ig6r. The allergens in ragweed pollen. J. Immunol., 87, 439-446.

Richter M., Sehon A. M., 1960. The allergens of ragweed pollen. J. Allergy, 31, I. I I-I33.

Richter M., Delorme P., Grant S., Rose B., ig62. The uptake of ragweed pollen allergens by polyaminostyren. J. Biol. Physiol., 40, 47 I-475 et 519-528.

Ridi M. S. el, Mofty A. el, Khalifa K., Soliman L., ig6o. Gonadotropic hormone in pollen grain of the date palm. Chem. Abs., 54, 7492 d.

Robbins K. C., WU H., BARAN P., Mosko M. M., Ig63. Isolation of non dialysable allergens and antigens from low ragweed pollen. J. Immunol., 91, 354-36r.

Rodkiewicz B., 196r. Determination of deoxyribonucleic acid by Feulgen photometry in the nuclei of pollen grains. Chem. Abs., 55, $1808 \%$.

Samorodova-BIaki G. B., ig62. Pollen fertility and content of carotens in the anthers of potatoes. Chem. Abs., 57, 2589 a.

Schanderl H., Staudenmayer T., Werkesmeister P., 1963. Sugars in poilen grains. Nalumissenschaften, 30, 444 .

Schloesser K., 1962. Cytological and cytochemical investigation of pollen tube growth of sterile petunia. Chem. Abs., 57, I $488 \mathrm{c}$.

ScotT R. W., Stroti M. J., ig62. Extraction and identification of lipids from loblolly pine pollen. Phytochemistry, 1, 189-193.

Shpakova V. M., ig6o. Chemical composition of grape pollen. Chem. Abs., 54, 13284 $i$.

ShPakova V. M., Ig62. Chemical composition of pollen from several fowers and grape. Chem. Abs., 57, I 551 I $i$.

Singh R. N., Randhana G. S., Sharma D. K., 196r. Pollen storage and pollen germination in fruit crops. Indian J. Hort., 18, 85-96.

Stanley R. G., Linskens H. F., I964. Enzyme activation in germinating petunia pollen. Nature, 203, $542-544$.

Stanley R. G., Young I. C. T., i962. DNA synthesis or turnover non dialysable jollen cells of pine. Nature, 196, I228-1230.

Stanley R. G., Poostchi I., I962. Endogenous carbohydrates organic acids and pine pollen viability. Silvae Genet., 11, I-3.

TanakA K., rg6o. The pollen germination and pollen tube development of P. densiflora. Chem, Abs., 54, 2. $339 \mathrm{~d}$.

'Tupy J., I962. Radiorespirometric study of the utilisation of exogenous sucrose, glucose and fructose by germination apple pollen. Chem. $A b s$., 56, $14637 d$. 
Tupy J., 1963. Free amino acids in apple pollen from the point of vew of its fertility. (hem. Abs., 58, $10468 \mathrm{e}$.

Takiguchi K., HotTa K., 1964. The riboflavin content of pollen. Chem. Abs., 61, 16436f.

Tulecke W., Weinstein L. H., Ruttner A., Iaurencot H. J. jr, 1963. Biochemical and physiological studies on tissue culture and the plant parts from which they were derived. Chem. Abs., 58, In682 h.

VANYNSKi B. F., FAS D., г тбг. Nucleotide composition and contents of RNA and DNA of plant pollen. Biokhimya, 26, 1034-1039.

VASIL I. K., 1964. The pollen germination of certain solanaceae. Chem. Abs., 62, $12580 e$.

Zielinski-Olez Q. B., I 963 . Effects of levels of $\mathrm{Mn}$ in culture medium on pollen germination and pollen growth of prune and pear. Proc. Amer. Soc. hort. Sci., 83, 205-209.

Zolotovich G., Sechevsha MI., Decheva R., 1964 . Changes in the composition of the sugars and in enzyme activity on storage of rose pollen. Chem. Abs., 61, 9771 $b$. 